\title{
SOLAR AND WIND ELECTRICITY IN AUSTRALIA
}

\author{
Andrew Blakers \\ Centre for Sustainable Energy Systems \\ Australian National University, Canberra, 0200 \\ ph 026249 5905; email andrew.blakers@ anu.edu.au
}

\begin{abstract}
This paper examines the renewable generation of electricity in Australia from photovoltaics $(P V)$, solar thermal electricity (STE) and wind. PV, STE and wind have immense resources and small environmental impacts even when deployed on very large scales. They are the only fully sustainable technologies able to completely replace fossil and nuclear electricity generation during this century. Wind energy is now a low cost generation technology, and is likely to provide 10 per cent of the world's electricity by 2020. PV has found attractive niche markets and has an annual growth rate of 30 per cent per year. STE is a promising technology but presently lacks niche markets to enable an industry to get started. The Australian Government is offering attractive assistance for renewables, although the lack of research \& development funding in these programs is a serious shortcoming.
\end{abstract}

\section{Introduction}

There are three large-scale energy sources available for the production of electricity, namely nuclear energy, fossil fuels and solar energy. Nuclear energy from fission has severe problems relating to waste disposal, reactor accidents, nuclear weapons proliferation and nuclear terrorism. Nuclear fusion is still many decades away from commercial utilisation. Fossil fuels are the principal cause of the enhanced greenhouse effect and are subject to resource depletion, in addition to other problems. Solar energy is available on a massive scale, and collection and conversion methods usually (but not always) entail few environmental or social problems.

In addition to these three large sources of energy there is tidal and geothermal energy. These are available on a relatively small scale at a limited number of sites. In the case of tidal energy there is usually a major environmental impact associated with the construction of what amounts to a coastal hydro scheme.

Solar energy includes both direct radiation and indirect forms such as biomass, wind, hydro, ocean thermal and waves. Wave, ocean thermal and hydro sources are geographically limited. Biomass energy has a very low overall efficiency $(<1$ per cent) and ultimately competes with food and timber production or with habitat preservation when used on a large scale. Photovoltaics, solar thermal electricity and wind energy are the only renewable energy technologies in sight that can provide very large quantities of sustainable electricity with a reasonable ( $>10$ per cent) overall efficiency in order to limit land use requirements.

This paper examines the technical and economic status and future prospects in Australia of photovoltaics, solar thermal electricity and wind energy. 


\section{The Energy Resource}

\subsection{Wind Energy}

Wind energy is approximately proportional to the cube of the wind speed. Thus the cost of wind energy at a site with an average wind speed of $6 \mathrm{~m} / \mathrm{sec}$ would be double that at an $8 \mathrm{~m} / \mathrm{sec}$ site. Roughly speaking, an average wind speed at $50 \mathrm{~m}$ above ground of $6 \mathrm{~m} / \mathrm{sec}$ is marginal for a wind farm. Average speeds of 7-8 m/sec are good while $9 \mathrm{~m} / \mathrm{sec}$ and above are exceptional. Wind speed increases with distance above the ground. This is called wind shear. The reason for the increase in wind speed with height is that the roughness of the ground slows the wind (which has a speed of zero at ground level). The roughness class of a landscape is a significant parameter when estimating likely wind energy output from a wind farm. The optimum tower height of a wind generator is a trade off between tower cost and increased energy production [1].

Sophisticated software packages are available for evaluating a proposed wind farm. They take into account surface roughness and topography, wind shear, the proximity of the sea or lakes, altitude, air temperature and the characteristics of the wind generators. They allow optimal siting of the wind generators or of wind monitoring stations to gather further wind data. They estimate annual electricity production. They provide photo-realistic views of the wind farm from any point to assess visual amenity and calculate noise impacts and perform economic calculations in an integrated fashion [2].

Australia has excellent wind resources by world standards [3]. The southern coastline lies in the "roaring forties" and hundreds of sites have average wind speeds above 8 or even $9 \mathrm{~m} / \mathrm{sec}$ at $50 \mathrm{~m}$ above ground (hub height of a modern wind generator). SW Western Australia, SE South Australia, western Victoria, northern Tasmania and elevated areas of NSW and Queensland all have very good wind resources. Several states engaged in systematic wind speed monitoring in the 1980s and 1990s, the results of which are publicly available [3]. Unfortunately much of the recent wind monitoring is commercial-in-confidence.

Up to 0.5 million $\mathrm{km}^{2}$ in southwest Western Australia may have average wind speeds above $6 \mathrm{~m} / \mathrm{sec}$ at $60 \mathrm{~m}$ height. This is 30 times more land than would be required to provide all of Australia's electricity from the wind. It is clear that Australia has much more land with good wind than would be required to meet our entire electricity demand.

\subsection{Photovoltaics and solar thermal}

At noon on a sunny day the solar intensity is about $1 \mathrm{~kW} / \mathrm{m}^{2}$. Global solar radiation comprises direct beam and diffuse light. Direct beam light comes directly from the sun, and is generally 60-85 per cent of the annual total. Diffuse light comes from the sky, clouds and the ground. Concentrating systems can only use direct beam light and require sun tracking. Most non-concentrating solar thermal systems (including domestic solar hot water systems) also only use direct beam light. The reason for this is that direct beam light is far more intense than scattered light, which tips the balance of thermal gains and losses heavily in favour of gains. In contrast, non-concentrating photovoltaic systems, which are not subject to thermal losses, can use scattered light. 
Concentration requires accurate sun-tracking, which can be in one axis or two. Systems without tracking or with single axis tracking or where the receiver does not move (such as power towers), incur cosine losses. Cosine losses become significant whenever the sun is reflected from mirrors at a moderate or large angle of incidence. Two axis tracking is more expensive than one axis tracking but delivers 10-40 per cent more energy over the course of a year, depending on the ratio of direct beam to diffuse light, the latitude and the collector configuration.

In contrast to wind energy, average global solar radiation is fairly uniform. The best global solar radiation in Australia (in the north west) is only twice as good as the worst (south west Tasmania). However, direct beam radiation is less uniformly distributed than global solar radiation. Australia has excellent solar energy resources by world standards. In particular, it has good direct beam irradiation in the arid interior.

$\begin{array}{lcclcc} & \mathbf{M J} / \mathbf{m}^{\mathbf{2}} / \mathbf{d a y} & \text { Relative } & & \mathbf{M J} / \mathbf{m}^{\mathbf{2} / \mathbf{d a y}} & \text { Relative } \\ \text { Aust average } & 26.3 & 92 \% & \text { Laverton } & 15.6 & 55 \% \\ \text { Adelaide } & 18.0 & 63 \% & \text { Longreach } & 27.4 & 96 \% \\ \text { Albany } & 15.8 & 55 \% & \text { Melbourne } & 15.6 & 55 \% \\ \text { Alice Springs } & 27.8 & 97 \% & \text { Mildura } & 22.1 & 77 \% \\ \text { Brisbane } & 17.5 & 61 \% & \text { Mt Gambier } & 14.5 & 51 \% \\ \text { Cairns } & 17.0 & 59 \% & \text { Oodnadatta } & 27.7 & 97 \% \\ \text { Canberra } & 16.5 & 58 \% & \text { Perth } & 22.9 & 80 \% \\ \text { Darwin } & 26.1 & 91 \% & \text { Port Hedland } & 28.6 & 100 \% \\ \text { East Sale } & 14.0 & 49 \% & \text { Rockhampton } & 20.7 & 72 \% \\ \text { Forrest } & 25.4 & 89 \% & \text { Sydney } & 16.3 & 57 \% \\ \text { Geraldton } & 25.3 & 88 \% & \text { Tennant Creek } & 23.5 & 82 \% \\ \text { Halls Cr } & 28.4 & 99 \% & \text { Townsville } & 19.3 & 67 \% \\ \text { Hobart } & 14.3 & 50 \% & \text { Wagga } & 22.2 & 78 \% \\ \text { Kalgoorlie } & 21.5 & 75 \% & \text { Williamtown } & 20.4 & 71 \% \\ \text { Launceston } & 15.1 & 53 \% & & & \end{array}$

Table 1: Average daily direct beam radiation on a 2 axis tracking surface (data from [4]). The columns labelled "relative" are a comparison with Port Hedland. The Australian average refers to the land mass average as distinct from the population-weighted average. $1 \mathrm{kWh}=3.6 \mathrm{MJ}$

\section{Wind Energy}

\subsection{Technology}

Modern wind generators have capacities in the range 600 to 2,000 $\mathrm{kW}$. Typical machine size is likely to increase to 2,000 to $5,000 \mathrm{~kW}$ by 2010 . They have $40-70 \mathrm{~m}$ high tubular steel towers on a concrete foundation and have 3 blades, each 20-40 m long. The nacelle at the top of the tower contains the blade anchors, gear box, generator, power electronics, brake assemblies and motors to rotate the nacelle to face into the wind and to rotate the pitch of the blades in order to control power extraction from the wind. They are computer-controlled and centrally monitored, with many safety features. They have availabilities above 98 per cent and will last more than 20 years, although replacement by a larger machine after 10-15 years to take advantage of a good wind-site is common.

Wind generator efficiency depends on wind speed. It averages about 25 per cent and peaks at about 45 per cent under ideal wind conditions. The theoretical maximum efficiency is 59 per cent. Wind 
generators are designed to begin producing power at a wind speed of 4 to $5 \mathrm{~m} / \mathrm{sec}$ and to cut out for safety reasons at a wind speed of 20 to $30 \mathrm{~m} / \mathrm{sec}$. The capacity factor of a generator is defined as the actual annual energy output (MWh/yr) divided by the product of the rated output (MW) and the number of hours in a year (8,760). For example, the Vestas V66 1650/66 has a capacity factor of up to 32 per cent at a site with an average wind speed at $50 \mathrm{~m}$ above ground of $7.5 \mathrm{~m} / \mathrm{sec}$.

A rough landscape will reduce wind speeds. It also has the effect of increasing stress on the wind generator. The reason for this is that the blades will experience markedly different wind forces and hence mechanical stress over their rotational cycle, since the wind speed at the blade tip when it is at its highest point will be substantially larger than when it is at its lowest point. Deployment of wind turbines in shallow seas off northern Europe has commenced, to take advantage of increased wind speeds and also to increase the number of available sites. Another advantage of a maritime location is that turbulence is reduced, which reduces stress on machine components leading to lower maintenance costs despite the presence of salt.

\subsection{Markets}

Generation of wind energy using modern turbines has been growing rapidly since about 1980 . This interest had its origins in the oil embargoes of the 1970s. The US Government offered attractive tax breaks in the period to 1985, which depended on the power rating of the turbines. Despite widespread failure of wind generators in the early 1980s, one class of machine proved to be sturdy, reliable and economically viable. These were 50-60 kW machines from Europe, mostly from Denmark. The Danes built their machines with large safety margins and started with small machines on which the stresses were similar to known and reliable technologies such as aircraft. Over the years Danish and other European manufacturers gradually increased their machine size as experience was gained, but never at the expense of reliability. By the end of the 1990s the Danes had 50 per cent and European manufacturers 80 per cent of the world market.

Globalisation of the industry is occurring, leading to the emergence of major manufacturers who establish joint ventures and technology transfer agreements with companies in emerging markets. Five manufacturers account for 70 per cent of current sales. World wide installed wind generator capacity passed 10 GW in 1998 [1]. Europe (mainly Germany, Spain and Denmark) has 65 per cent of installed capacity followed by the USA ( 21 per cent), India ( 9 per cent), China ( 2 per cent) and all other countries (3 per cent). 


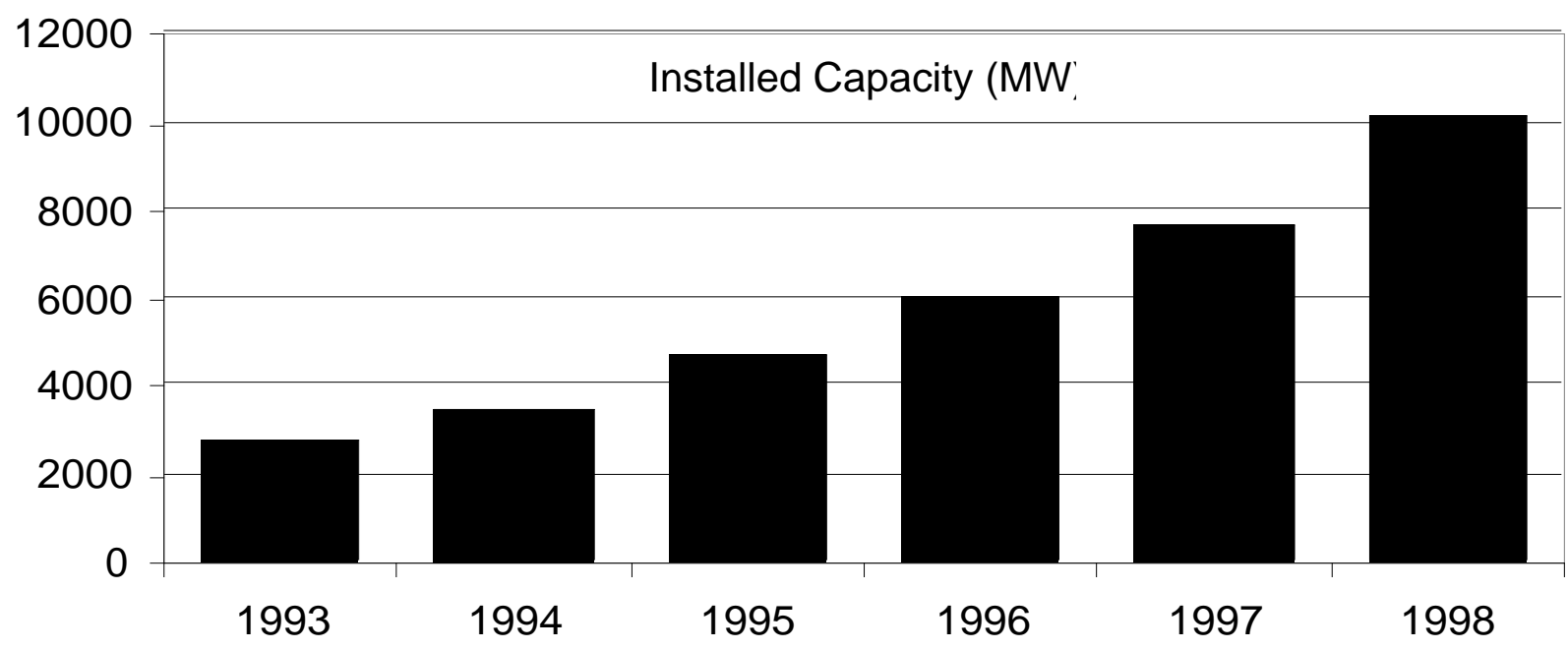

Figure 1: The world's installed wind energy capacity year by year [1]. The average annual compound growth rate since 1993 has been 26 per cent/year.

Denmark generates 10 per cent of its electricity from the wind. The Government intends to generate 14 per cent and 50 per cent of Denmark's electricity from the wind by 2003 and 2030 respectively. Many other countries have large wind resources and are likely to have a substantial fraction of their electricity generated from the wind by 2030 . The wind energy industry has set itself a target of 10 per cent of the world's electricity by 2020 [5].

In Australia, a number of companies sell small wind generators $(2-20 \mathrm{~kW})$ for remote area applications. Some are exported. An example is Westwind (located in south Perth), which has product development support from the Australian CRC for Renewable Energy and the University of Newcastle.

Australia has three wind farms in the Megawatt range: Esperence (2 MW, Western Power), Crookwell (5 MW, Pacific Power) and Windy Hill on the Atherton Tablelands (12 MW, Stanwell Corporation), Planning and (construction) is well advanced for wind farms of capacity of about 22 MW at Albany (Western Power), $10 \mathrm{MW}$ at Blayney (Pacific Power) and at the NW tip of Tasmania (Hydro Tasmania).

\section{Solar Thermal Electricity}

Most solar thermal electricity technologies use mirrors to concentrate sunlight onto a receiver. The resulting heat is ultimately used to generate steam, which passes through a turbine to produce electricity. Two non-concentrating exceptions are solar chimneys and solar ponds. The usual ways of concentrating sunlight are listed below. These concentration methods are equally applicable to concentrating PV systems.

- point focus concentrators (dishes)

- line focus concentrators (troughs, both reflective and refractive)

- central receivers (heliostats and power towers)

\subsection{Dishes}


Point focus sun tracking parabolic solar concentrators have been available for more than 100 years [6]. High concentration ratios (500-2,000) and temperatures $\left(>1,500^{\circ}\right)$ can be achieved, which can be used to drive chemical reactions, raise steam or operate a thermoelectric or Stirling converter. Australia has a leading position in this field. Two groups in Australia have built large dishes. These are the Australian National University in Canberra and Solar Systems in Melbourne.

The ANU Energy Research Centre (ERC) built one of the world's first large solar thermal power stations at White Cliffs in western NSW in 1978. The 14 dishes, each $20 \mathrm{~m}^{2}$, operated for a number of years supplying electricity generated by raising steam. Subsequently the ERC constructed a $400 \mathrm{~m}^{2}$ dish at ANU. It is a space frame design whereby the structure is supported using accurately machined steel rods connected to steel nodes. Steam raised at the focus of the dish is passed to a ground-mounted steam engine for production of electricity [7]. It is envisaged that a large power station would have many dishes, each feeding steam to a central steam turbine for electricity production. A similar dish has been sold to the Israel National Solar Energy Centre. The ERC is a participant in a Showcase project at Mt Isa whereby solar steam will be fed into a conventional power station as a pre-heater to reduce consumption of fossil fuels. A proposal has been made to construct a $24 \mathrm{MW}$ power station in South Australia comprising a solar collector field of ERC designed dishes and a gas turbine.

Solar Systems has constructed a dish of about $100 \mathrm{~m}^{2}$ for concentrating light onto a photovoltaic receiver. CSIRO at Lucas Height recently purchased a Solar Systems dish for solar thermal and thermochemical applications. Solar Systems purchased the White Cliffs solar thermal plant and converted it to a concentrating PV system.

Dish/Stirling systems are stand-alone systems which have a Stirling cycle engine mounted at the focus of a dish concentrator. Efficiencies above 25 per cent have been reported. This is an attractive system since it has flatter economies of scale than a steam cycle STE system, and would be able to compete with PV in moderate scale applications.

\subsection{Linear Concentrators}

Linear concentrators such as parabolic troughs typically have concentration ratios between 10 and 80 . Since experimental systems are relatively cheap, many have been constructed. The use of linear concentrators for stand alone solar thermal electricity is limited by the fact that it is difficult to reach temperatures in excess of $400^{\circ}$, whereas the operating regime of a standard high efficiency steam turbine is above $500^{\circ}$. This problem can be avoided if the system acts as a pre-heater for a standard fossil fuel powered generation unit.

The world's only large STE system is a grid connected 354 MW linear system in the USA. This system has 2.5 million $\mathrm{m}^{2}$ of parabolic reflecting mirrors which heat oil or water passing through a tube at the focal line. The system acts as a preheater for a conventional gas generator. It was built by the Luz Company in the 1980s with substantial assistance from tax credits. Luz went broke in 1991 when the credits were withdrawn. Pilkington, who manufactured the glass for the system, subsequently acquired the rights to the technology [8].

Three Australian groups are active in the area of linear concentrators. They are the Centre for Sustainable Energy Systems at the Australian National University (CSES), a group led by David Mills (Sydney University) and Graham Morrison (UNSW) and a group at Yeomans. The CSES has 
developed a photovoltaic concentrating system using tracking parabolic reflecting glass mirrors. They will also be used for hot water production and could easily be converted to steam production. As part of the program a novel glass mirror has been developed which could have wide applications.

Mills and Morrison [9] are developing a system called a compact linear Fresnel reflector. This system is equivalent to a power tower in many respects. It has several long north-south oriented fixed receivers mounted $10 \mathrm{~m}$ above the ground which receive reflected light from long rows of large mirrors aligned on north-south axes. Cosine losses from having a fixed receiver are reduced by allowing each mirror row to direct light to the receiver to the east or the west, depending on the time of day. Fixed receivers avoid the need for rotary joints in steam lines and minimise weight on the trackers. This system has lower capital and operational costs than dish concentrators, and requires less land since the reflectors shade each other less. However, its annual thermal output is only about 70 per cent as large as a dish concentrator per unit area of mirror and it is not capable of reaching high temperatures. A Showcase project with $17,000 \mathrm{~m}^{2}$ of mirror is to be constructed which will act as a pre-heater for a conventional coal fired power station operated by Stanwell. The system will rely on mirror technology developed at ANU.

Yeomans [10] is developing a low cost 2 axis tracking linear concentrator. An array of flat mirrors track the sun in one axis and reflect light up to a receiver. The whole system is mounted on a float in a pond to allow rotation (2nd axis of tracking). Ambitious claims are being made for costs and performance.

\subsection{Power Towers}

Power towers comprise fields of sun tracking mirrors, which direct sunlight up to a fixed central tower for conversion to electricity. Both thermal and photovoltaic systems have been constructed [11]. High concentration ratios (300-1,500 suns) and high temperatures $\left(500-1,500^{\circ}\right)$ are achievable. A $10 \mathrm{MW}$ system has been constructed in California. The advantage over dishes and linear concentrators is that the receiver does not move. This avoids the need for rotary joints for high pressure/temperature steam lines, and substantially reduces the weight on the tracking system. The disadvantages are that only large scale (> $10 \mathrm{MW}$ ) systems are likely to be competitive and that the "cosine" losses are substantial. There is no power tower work in Australia. The high cost of even an experimental power tower inhibits rapid development.

\subsection{Low temperature electricity production}

Solar ponds are shallow (1 to $3 \mathrm{~m}$ ) pools of saline water. Sunlight is absorbed at the bottom of the pool, which rises to 60-80 degrees. A salinity/density gradient is established (eg 1 per cent salinity at the surface and 30 per cent at the bottom) which suppresses the tendency of the hot water to rise to the surface. A low temperature heat engine can be used to extract electricity, although at low efficiency. Aquaculture, salt and hot water are other possible products of solar ponds. The largest solar pond built to date was a $5 \mathrm{MW} 0.25 \mathrm{~km}^{2}$ plant, which operated for a few years in Israel with an efficiency of 2 per cent in the late 1980s. A number of solar ponds have been constructed in Australia. A consortium of RMIT, Geo-Eng and Pyramid Salt was recently awarded an RECP grant by the Australian Greenhouse Office of $\$ 550,000$ to construct a solar pond. Electricity generation costs of around $20 \mathrm{c} / \mathrm{kWh}$ are claimed for the technology, together with the possibility of other economic outputs such as salt and agricultural products [12]. 
Solar Chimneys consist of large areas of glass surrounding a central chimney that is several hundred metres high. Solar energy warms the air beneath the glass which is drawn up the chimney through a wind turbine by a pressure difference. The higher the chimney the greater is the conversion efficiency. Chimneys of up to $1 \mathrm{~km}$ in height have been proposed. A large system was constructed in Spain but has been dismantled. Energy costs seem to be higher than from other technologies, and efficiencies are low.

\subsection{Solar Thermochemistry}

Concentrated solar thermal energy can be used to drive chemical reactions, which store energy. Two examples are the ammonia cycle and steam reforming of methane. The ammonia cycle starts with the endothermic reaction $2 \mathrm{NH}_{3} \rightarrow \mathrm{N}_{2}+3 \mathrm{H}_{2}$ which has no side reactions. Nitrogen and hydrogen can be safely stored together for long periods and transmitted by pipe in a similar way to natural gas. Ammonia synthesis from the $\mathrm{N}_{2}$ and $\mathrm{H}_{2}$ with the help of a catalyst recovers the stored thermal energy. Thus 24 hour power and seasonal storage is possible. Ammonia synthesis is a well-understood reaction and is one of the world's largest chemical industries (for fertiliser). Research in this area concentrates therefore on the dissociation reaction. ANU has a leading position in this area [13].

An important feature of the ammonia cycle is that dissociation of ammonia occurs at the focus of a solar concentrator but the reaction products $\left(\mathrm{N}_{2}\right.$ and $\left.\mathrm{H}_{2}\right)$ are removed from the reaction chamber at room temperature via a heat exchanger. This eliminates thermal losses and rotary steam joints associated with steam transmission to a central turbine in a large solar power system. Cost estimates indicate that avoidance of the thermal losses and costs of handling steam is sufficient to balance the cost of the ammonia dissociation and synthesis system. Thus 24 hour solar power is potentially available without a cost penalty.

Steam reforming of methane increases the energy content of the fuel via the endothermic reaction $\mathrm{CH}_{4}+\mathrm{H}_{2} \mathrm{O} \rightarrow \mathrm{CO}+3 \mathrm{H}_{2}$. Gasification of coal can also be accomplished using solar heat via the reaction $\mathrm{C}+\mathrm{H}_{2} \mathrm{O} \rightarrow \mathrm{CO}+\mathrm{H}_{2}$. There are problems with carbon cycles caused by side reactions. In addition, they are not greenhouse neutral. CSIRO is working in this area and has acquired a Solar Systems parabolic concentrator for this research.

\section{Photovoltaics}

Photovoltaics (PV) is an elegant but expensive technology. It has found widespread use in niche markets such as consumer electronics, remote area power supplies and satellites. The cost of PV systems is not a strong function of scale, which means that PV systems are often the most economical energy source for small applications. About 85 per cent of the world photovoltaic market is serviced by crystalline silicon (c-Si) solar cells. This dominance is likely to continue for many years.

\subsection{Crystalline silicon solar cells}

Crystalline silicon has many advantages over competing materials. Silicon dioxide is the most abundant mineral in the Earth's crust. Silicon is non-toxic. Crystalline silicon solar cells have high conversion efficiencies (up to 28 per cent under concentrated sunlight) and are stable. They already have market dominance and acceptance. Crystalline silicon is the basis of the integrated circuit industry, which 
means that c-Si PV can share production equipment, infrastructure, education and R\&D with a much larger industry.

Silicon solar cells are made on p-type single crystal or multicrystal silicon wafers about $0.4 \mathrm{~mm}$ thick and $100-150 \mathrm{~mm}$ in diameter. These wafers are cut from ingots. The wafers are subjected to high temperature diffusion steps to create an n-type region junction just beneath the upper surface of the solar cell, followed by the deposition of metal on each surface to allow extraction of electricity from the cell. The p-n junction that is formed acts like a one-way membrane for electrons. Photons of light absorbed by the silicon knock electrons off atoms. These free electrons move around the silicon crystal at random. If they cross the p-n junction into the n-type region they are unable to return. This gives rise to an excess of electrons in the n-region and a deficiency in the p-region, and a consequent voltage difference across the $\mathrm{p}-\mathrm{n}$ junction. If the top of the cell is connected to the rear of the cell via an external circuit containing a load or battery then electrical power can be extracted from the cell. The power output of the cell is in proportion to the incoming sun power.

Typical commercial c-Si cells are 10-15 per cent efficient; i.e. they will have a power output of 100-150 Watts per square metre at noon on a sunny day. They are packaged into modules, which have voltage and power outputs of about 16 volts and 60 Watts respectively. Guarantees of 20 years are available, and working lifetimes can be considerably in excess of this in non-maritime locations.

The cost of the crystalline silicon wafer is about half the cost of a finished PV module. The main motivation for the use of concentrating systems and non-silicon materials is the desire to reduce the wafer cost. Another approach is the use of thin films of crystalline silicon. In this approach silicon is deposited on a suitable supporting substrate with a thickness of less than 40 micrometers, which is one tenth of the normal thickness of a silicon wafer. In this way the cost of ingot slicing is avoided and the cost of the hyperpure silicon is almost eliminated, while retaining the many advantages of crystalline silicon.

Two large (> 30 people) research groups work in the area of c-Si solar cells in Australia. They are the Photovoltaic Special Research Centre at the University of NSW and the Centre for Sustainable Energy Systems at the Australian National University. These groups are well known internationally, particularly for their work on highly efficient silicon solar cells and advanced thin film c-Si solar cells. The ANU group is developing a new type of thin film c-Si cell using its Epilift technique, in conjunction with Origin Energy. Pacific Solar is a joint venture between the University of NSW and Pacific Power, which aims to commercialise a thin film c-Si solar cell deposited on glass.

Australia's only PV manufacturing plant is operated by BP Solar in Sydney. It produces solar cells and modules made from both single and multicrystalline silicon wafers. The new plant located at Homebush has a production capacity of $10 \mathrm{MW}$ per year.

\subsection{Concentrator systems}

Concentrator systems have a number of important advantages over conventional PV systems, the main one being that a cheap reflective or refractive surface is substituted for most of the solar cells. The inability of the concentrators to use direct beam sunlight is compensated for by the sun tracking of the system. An excellent review of concentrator systems has recently been published [14]. Troughs, dishes, power towers and Fresnel lenses can all be used to concentrate light onto solar cells, as described for 
solar thermal electricity. Since the solar cells are a relatively small part of a whole system cost, highly efficient solar cells can be afforded. These are generally high performance single crystalline silicon solar cells. Expensive gallium arsenide solar cells can be used in high concentration systems (500 to 1500 suns). Concentrator cell efficiencies are generally in the range 20 to 30 per cent.

Two Australian groups are working in the area of PV concentrators. The ANU has developed a photovoltaic/trough concentration systems which comprises two axis sun tracking parabolic glass mirrors and a receiver at the focal line of the troughs, with cells mounted on the under surface. Solahart (a major solar water heater manufacturer) has a license for the technology. ANU and Solahart have constructed a $20 \mathrm{~kW}$ prototype system in Perth [15]. Solar Systems in Melbourne has developed a PV dish concentrator system, and is using high-performance silicon and gallium arsenide solar cells.

\subsection{Thin film technologies}

Several non-silicon materials are being investigated for non-concentrating PV applications. These include amorphous silicon, cadmium telluride, copper indium diselenide and titanium dioxide. Very thin layers of these materials are sufficient to absorb most of the sunlight. They are deposited on a suitable substrate by a variety of means. On the one hand the cost per square metre of these materials is lower than that of silicon. On the other, they have substantially lower stable efficiencies than silicon solar cells. Some of the materials (eg cadmium) are toxic while others (eg indium) are rare. It has not been easy for these materials to penetrate world markets. Sustainable Energy Technologies in Queanbeyan is developing titanium dioxide solar cells, and is the only Australian company working in this area.

\subsection{World Markets}

Worldwide PV sales have been increasing at a rate of about 30 per cent per year for the past few years. In 1999 total sales reached $200 \mathrm{MW}$. Much of this growth arises from Government programs to subsidise the installation of rooftop photovoltaic systems. Virtually all PV sales are for nonconcentrating systems based on crystalline silicon solar cells. Concentrators cannot compete directly with electricity from State grids, and lack the niche markets that have accommodated conventional PV modules. If and when a suitable market for large-scale PV systems opens, whether driven by subsidies or by other means, it is expected that concentrator systems will be competitive with conventional PV systems.

\section{Environmental Considerations}

Wind generators have minimal environmental impact. Land alienation associated with wind energy production is among the lowest of the electricity generation technologies. The site is preferably cleared farmland to minimise interference to the wind by trees. Each tower occupies about $40 \mathrm{~m}^{2}$ and the towers are spaced 5 to 7 rotor diameters apart. About 2 per cent of the area spanned by a wind farm is actually alienated, and normal farming operations continue around the tower. The wind farm amounts to a second cash crop for the farmer, who leases the land to the wind energy company.

Wind generators are designed to minimise noise. At distances greater than 7 rotor diameters from the machine (the minimum distance to a dwelling) the noise from a wind generator is difficult to detect above the background noise caused by the wind. They cause minimal interference to telecommunications. Wind generators are rarely associated with bird kills. They should not be sited near 
major rookeries, but long experience in Europe has shown that birds rarely fly into the blades. The operational time required to recover the energy used in machine construction is less than 3 months.

The only significant environmental problem for wind generators is visual amenity. The tower shape, height and colour can be adjusted to help them blend into the landscape. Some wind farms are installed without opposition while others are fiercely opposed. The fact that wind speeds are highest near the coast can lead to conflict, particularly in areas of natural beauty. It has often been the case that opposition to a wind farm diminishes if a small number of machines are installed initially to give people experience with the technology. There has been a very positive attitude to wind farms in northern Europe, with many local people buying shares in wind farms. However, in Britain support for wind energy has been patchy. Careful siting and a sensitive attitude to local residents minimises opposition. Some local governments are organising pre-approvals for wind farms so that a wind farm developer does not have the risk of costly and time-consuming court battles.

Solar thermal power stations operate without noise, greenhouse or waste gas emissions or electromagnetic interference. They generally pose minimal safety hazards to neighbours. Problems of visual amenity are small since they are generally located in regions far from areas of outstanding natural beauty. The materials used in the construction of a solar power station are mainly steel, concrete and glass, which are relatively environmentally benign and mostly recyclable. The energy payback time of a solar thermal power station is less than one year.

Land alienation associated with solar thermal energy production is small. A solar steam system will generate about $50 \mathrm{MW} / \mathrm{km}^{2}$. The amount of land required to replace Australia's entire fossil fuel generation of electricity with solar generation is about $1500 \mathrm{~km}^{2}$, or 0.02 per cent of the land area. A large proportion of this land (the area between collectors, which must be spaced out to avoid shading each other) will be available for agricultural use or can be left as natural vegetation.

Thermochemical power stations pose the potential hazard of a spillage of the working fluid (eg ammonia). Such a hazard is small since the power station would not be close to dwellings, and there is long experience with the safe handling of such materials.

Photovoltaic power generation has a similarly small environmental impact to solar thermal generation. The area of roof in Australia is sufficient for the replacement by photovoltaics of Australia's entire fossil fuel generation of electricity. The energy payback time of PV is presently 3 to 5 years. This is very likely to decline to 1 to 2 years over the next decade with the introduction of thin film and concentrating PV systems.

\section{Economics}

\subsection{Energy cost calculations}

The main factors to be considered when calculating the cost of solar and wind energy are:

- Annual global or direct beam solar energy or average wind speeds

- The solar collector efficiency or wind generator power curve

- The system cost

- The installation cost 
- The cost of connection to a high voltage transmission line

- Operations and maintenance (O\&M) costs

- System availability

- System lifetime

- The real discount rate

The levelised energy cost from a power system is given by the following equation:

Energy cost $=\frac{C}{E} \times\left[\frac{\alpha}{\left(1-e^{-\alpha t}\right)}+M\right]$

Here $\mathrm{C}$ is the fully installed cost of the system (\$), $\mathrm{E}$ is the annual energy output of the system ( $\mathrm{kWh} /$ year), $\alpha$ is the real discount rate (per cent per year), $\mathrm{t}$ is the system lifetime (years), $\mathrm{e}$ is the natural logarithm basis and $\mathrm{M}$ is the annual O\&M cost expressed as a percentage of the initial capital cost of the system. The discount rate is a crucial parameter, as can be seen in the tables below. If a high rate is chosen then future costs are heavily discounted. This includes both fuel and environmental costs. A high discount rate strongly favours fossil fuel power stations.

\subsection{Wind Energy}

The current cost [1] of a $600 \mathrm{~kW}$ wind generator when ordered in large numbers ( 50 MW) is US $\$ 400,000$ to US $\$ 500,000$. Installation costs amount to US $\$ 100,000$ to US $\$ 150,000$, giving a total of US $\$ 500,000$ to US $\$ 650,000$. These figures are for installation in readily accessible regions with easy access to high voltage power lines. A figure of US $\$ 1,100 / \mathrm{kW}$ installed is used in the energy cost calculations below. This cost is only achieved if widespread installation of wind generators is taking place, a situation that prevails in northern Europe and Spain but not in Australia at present.

Manufacturing scale and technology continue to increase, and machine efficiencies continue to improve. Further cost reductions to around 50-60 per cent of current prices are confidently expected by 2020 [1], partly due to technical improvements and partly to large increases in manufacturing volume. If 10 per cent of the world's electricity comes from the wind in 2020 then annual sales will have increased by a factor of 50, which corresponds to an annual compound growth rate of 13 per cent/year. This is just half the average growth rate achieved in the 1990s, and should be readily achievable in the context of a response to global warming.

Operations and maintenance costs are around 1.0 to 1.5 per cent of the installed cost per year for new machines, and around 3 per cent for older machines. A figure of 2 per cent is used in the energy cost calculations. The most important parameters in the calculation of wind energy costs are the wind speed and the assumed real discount rate. Enough experience has now been gained with wind energy to allow it to be classed as a low technical risk investment. Levelised wind energy costs are listed in Table 2 in Australian dollars (assuming an exchange rate of A $\$ 1.00=\mathrm{US} \$ 0.65$ ).

\begin{tabular}{|l|c|c|c|c|}
\hline & \multicolumn{4}{|c|}{ Average wind speed at 50 m height } \\
\hline & $6 \mathrm{~m} / \mathrm{sec}$ & $7 \mathrm{~m} / \mathrm{sec}$ & $8 \mathrm{~m} / \mathrm{sec}$ & $9 \mathrm{~m} / \mathrm{sec}$ \\
\hline Discount rate & \multicolumn{4}{|c|}{ Energy Costs (c/kWh) $(\mathbf{A} \$)$} \\
\hline $5 \% /$ year & 10.0 & 7.1 & 5.5 & 4.6 \\
\hline
\end{tabular}




\begin{tabular}{|l|c|c|c|c|}
\hline $7 \% /$ year & 11.4 & 8.1 & 6.2 & 5.2 \\
\hline $10 \% /$ year & 13.7 & 9.7 & 7.5 & 6.3 \\
\hline $15 \% /$ year & 18.0 & 12.7 & 9.8 & 8.2 \\
\hline
\end{tabular}

Table 2: Wind energy costs. Based on a 1.65 MW Vestas V66 1650/66 machine with $66 \mathrm{~m}$ rotor diameter; hub height of $60 \mathrm{~m}$; fully installed cost of US $\$ 1,100 / \mathrm{kW} ; 98 \%$ availability; 2\%/year O\&M; 20 year machine life; landscape roughness class of 1.5; Weibull coefficient of 2.0 [1].

It is apparent that wind generators in good sites are fully competitive with fossil fuel generation unless the fossil fuel has a particularly low price. In Australia the latter situation prevails. The switchyard cost of electricity is around $4 \mathrm{c} / \mathrm{kWh}$ in the eastern states, and the cost to consumers is around 8-12 c/kWh. However, measures taken recently by the Federal Government are likely to improve the position of wind energy, as discussed below.

\subsection{Photovoltaics}

In the past the major PV market was in small niche applications, often in remote areas. The current market is dominated by heavily subsidised roof mounted PV systems. The energy cost from large photovoltaic systems is difficult to estimate because no large systems have been constructed without substantial subsidies.

A PV system comprises the PV modules and the balance of system costs. Balance of system costs of a grid-connected system include site preparation, component delivery, support structures, electrical cabling, installation costs, maximum power tracking and inversion. Most of these costs are area dependent, and hence efficient modules have an economic advantage.

The capital cost of PV systems is generally quoted in terms of dollars per peak watt. A peak watt is the output of the system under ideal conditions: $1 \mathrm{~kW} / \mathrm{m}^{2}$ illumination and 25 degree cell temperature. A de-rating factor of about 80 per cent compensates for elevated cell temperatures and other nonidealities. Small (1-10 kWp) PV systems currently cost A \$10-15/Wp (AC). Larger systems cost A $\$ 7-$ 10/Wp (AC). Operations and maintenance costs of non-concentrating PV systems are low since there are no moving parts. Concentrators must track the sun and require regular mirror cleaning. O\&M costs of 1 per cent of the capital cost per year are assumed in Table 3. The annual AC electrical energy output of a system with a rating of $\mathrm{M} \mathrm{kWp}(\mathrm{AC})$ is approximately given by $\{\mathrm{M} \times \mathrm{x}$,760 (hours/year) $\mathrm{x}$ capacity factor $\mathrm{x}$ availability $\mathrm{x}$ de-rating factor . The capacity factor at a particular site is given by the annual insolation $\left(\mathrm{kWh} / \mathrm{m}^{2} / \mathrm{yr}\right)$ on a fixed or tracking plane as appropriate (eg from [4]) divided by 8,760 $\mathrm{kWh} / \mathrm{m}^{2} / \mathrm{yr}$ and is typically $20-30$ per cent.

\begin{tabular}{|l|c|c|c|}
\hline \multicolumn{4}{|c|}{ Fully installed system cost (\$ per peak watt AC) } \\
\hline Discount rate & $\mathbf{\$ 2 / W p}$ & $\mathbf{\$ 5 / W p}$ & $\mathbf{\$ 1 0} / \mathbf{W p}$ \\
\hline $5 \% /$ year & 9.5 & 24 & 47 \\
\hline $7 \% /$ year & 11 & 27 & 55 \\
\hline $10 \% /$ year & 13 & 34 & 67 \\
\hline $15 \% /$ year & 18 & 45 & 89 \\
\hline
\end{tabular}

Table 3: Solar electricity costs (c/kWh). Based on: annual global insolation of $2,400 \mathrm{kWh} / \mathrm{m}^{2} /$ year (the Australian average); 98\% availability; de-rating factor of 80\%; 1\%/year O\&M; 20 year system life. 
Table 3 shows costs of PV systems that might be reached in the next decade. It is apparent that PV electricity costs are still well above the switchyard cost of coal-fired electricity in Australia. However, the cost of electricity in remote areas serviced by diesel generators is $18-35 \mathrm{c} / \mathrm{kWh}$, and even higher in small systems. PV is the recipient of attractive Federal Government assistance, which is opening up the diesel and other markets as discussed below.

\subsection{Solar Thermal Electricity}

The current cost of solar thermal systems is not available since there is no commercial market.

Estimates are available, but many of them seem rather optimistic. Large scale systems are likely to cost between $\mathrm{A} \$ 300$ and $\mathrm{A} \$ 800$ per $\mathrm{m}^{2}$ of mirror, depending on whether they are 1 or 2 axis tracking and whether or not the electricity generation equipment is included. The installed cost $(\$ / \mathrm{Wp})$ refers to the system cost divided by the power delivered as AC electricity to the grid under standard conditions (1 $\mathrm{kW} / \mathrm{m}^{2}$, direct beam). For example, a system costing $\$ 600 / \mathrm{m}^{2}$ of mirror with an overall efficiency of 15 per cent costs $\$ 4 / \mathrm{Wp}$. A de-rating factor accounts for the non-ideal conditions, which usually prevail.

Parabolic dishes have higher energy production (by 20-40 per cent) than single axis tracking linear concentrators. This is due to the elimination of cosine losses and also to higher efficiency for the conversion of solar energy to steam of a given quality. However, the collector cost will also be higher. Overall the cost of electricity production will be similar for the two systems. Operations and maintenance costs are difficult to estimate since only one large system operates anywhere in the world (Luz) and the real data is confidential. A figure of 3 per cent of the capital cost per year is used in the calculations in Table 4.

\begin{tabular}{|l|c|c|c|c|c|c|}
\hline & \multicolumn{6}{|c|}{ Fully installed cost (\$ per peak watt AC) } \\
\hline & \multicolumn{7}{|c|}{$\$ 2 / \mathrm{Wp}$} & \multicolumn{3}{|c|}{$\$ 3 / \mathrm{Wp}$} & \multicolumn{2}{c|}{$\$ 5 / \mathrm{Wp}$} \\
\hline & \multicolumn{6}{|c|}{ Energy Costs (c/kWh) (A\$) } \\
\hline Discount rate & 2 axis & 1 axis & 2 axis & 1 axis & 2 axis & 1 axis \\
\hline $5 \% /$ year & 9.5 & 14 & 14 & 21 & 24 & 34 \\
\hline $7 \% /$ /year & 11 & 15 & 16 & 23 & 27 & 39 \\
\hline $10 \% / y e a r$ & 13 & 18 & 19 & 27 & 32 & 46 \\
\hline $15 \% / y e a r$ & 17 & 23 & 25 & 35 & 41 & 59 \\
\hline
\end{tabular}

Table 4: Solar electricity costs $(\mathrm{c} / \mathrm{kWh})$. Based on: annual direct beam insolation on a 2 axis sun tracking surface of 2,670 kWh/m²/year (the Australian average); 95\% availability; de-rating factor of 90\%; 3\%/year O\&M; 20 year system life. A 1 axis tracking system is assumed to have $70 \%$ of the annual output of a 2 axis tracking system.

It has been suggested that the use of solar thermal to provide pre-heating for a standard fossil fuel powered turbine generation could have a major market application. Only the thermal energy collection components (transport, site costs, foundations, supports, mirrors, thermal receiver and steam pipes) are required, since the plant has its own electricity generation and cooling systems. In addition, the effective electrical conversion efficiency would be in the range 20-35 per cent (depending on steam quality produced by the STE system) rather than 12-20 per cent for a stand-alone STE system since the conventional power station has a high conversion efficiency. 
The first requirement for such a hybrid system is the construction of a complete fossil fuel generation system, including fossil fuel delivery infrastructure (pipelines, gas well, coal mine) and electrical connection to the grid. The second step is the purchase of at least 30 per cent of the fossil fuel required for a similarly sized pure fossil fuel plant. The last step is to decide whether to construct a solar powered pre-heater or simply to take more gas or coal at the marginal cost. The marginal cost excludes the delivery infrastructure, which has already been paid for, and will be well below the cost of the first megajoule of fuel. It is difficult to see the solar option being economic in the near term without substantial government inducements.

Morrison \& Mills [9] estimate that their 17,000 $\mathrm{m}^{2}$ Fresnel Reflector system operating as a pre-heater for a coal fired power station will produce the equivalent of $4.4 \mathrm{MW}$ (peak electrical output) at a cost of $\mathrm{A} \$ 7$ million ( $\mathrm{A} \$ 1.60 / \mathrm{W}$ or $\mathrm{A} \$ 412 / \mathrm{m}^{2}$ of mirror). This cost is for the thermal collection system (transport, site costs, foundations, supports, mirrors, thermal receiver and steam pipes) but does not include the electrical conversion equipment or cooling towers since the host coal fired power station already has these items.

The estimate of $\mathrm{A} \$ 412 / \mathrm{m}^{2}$ of mirror for the collection system is in agreement with the lower bound estimates made for the ANU PV/Trough system, and is reasonable for a large-scale system. A standalone version would, of course, cost substantially more. Based on Table 4, the delivered electricity cost would be 10 to $17 \mathrm{c} / \mathrm{kWh}$ depending on choice of discount rate. The marginal cost of the fuel in a conventional power station (coal or gas) is in the range $2-4 \mathrm{c} / \mathrm{kWh}$ (electrical). This is the figure with which a solar system acting as a pre-heater must compete. The subsidy of $2-4 \mathrm{c} / \mathrm{kWh}$ available under the $+2 \%$ program (see Section 8 ) is not sufficient to make STE systems economic.

\subsection{Cost comparison between photovoltaics and STE}

The relative cost of solar thermal power and photovoltaics is of interest. Photovoltaics has two branches: concentrating and non-concentrating. It is relatively easy to compare STE and PV concentration systems. The following costs are in common:

- the foundations, support structure and mirrors

- the installation cost (transport, site costs)

- the electrical interconnection cost

- the cost of disposing of excess heat

- operations and maintenance costs

These are the major costs. The following costs differ:

- for the PV system: solar cells, electrical cables and an inverter

- for the STE system: the thermal receiver, the heat transmission system and the energy conversion system

Overall, the costs per unit area are similar. The efficiencies are also similar. High performance commercially available (SunPower, ANU) silicon concentrator solar cells have an efficiency of 22-28 per cent under 10-1000 suns. Cells based on III-V compounds such as gallium arsenide are more expensive but have efficiencies in the range 30-33 per cent. These efficiencies are similar to those 
achievable with a Stirling engine or solar powered steam turbine. System lifetime and availability will be similar for PV and STE systems. The conclusion is that energy costs will be similar.

STE has steep economies of scale, which make small systems prohibitively expensive. This has prevented a vibrant market developing based on high cost remote area applications as has happened for PV. Another disadvantage relative to photovoltaics is that STE is unlikely to be co-located with an end user. This means that, in general, STE will need to compete directly with the base load switchyard cost of coal-fired electricity, which is presently rather low. A major advantage of PV is that it can be located on building roofs. Political and other considerations mean that the marginal energy cost with which PV electricity competes could be the consumer cost $(8-18 \mathrm{c} / \mathrm{kWh})$ rather than the fuel cost $(2-4 \mathrm{c} / \mathrm{kWh}$ electrical). One long-term advantage that STE does have over PV is that storage can be readily incorporated by way of thermochemistry or thermal mass. This advantage will be significant when solar power exceeds 20 per cent of total electricity production.

\section{An Australian Solar and Wind Electricity Industry}

\subsection{Federal Government Assistance}

Substantial assistance measures for renewable energy have recently been introduced by the Federal Government. The Australian Greenhouse Office was established to coordinate these measures.

The so called " $+2 \%$ " target, which was announced by the Prime Minister shortly before the 1997 Kyoto Conference, requires Australian utilities to source an additional 9,500 GWh of electricity from renewables by 2010 , with milestones in intervening years. The maximum penalty for failing to obtain sufficient renewable energy certificates is expected to be $4 \mathrm{c} / \mathrm{kWh}$. It is expected that the value of renewable energy certificates will be in the range 2 to $4 \mathrm{c} / \mathrm{kWh}$. The front-runners at present to supply the additional renewable electricity are solar water heaters, biomass and wind energy. Tranches for specific technologies have not been established. Tranches for promising new technologies such as PV or STE would have established a powerful incentive for these industries in Australia.

The sum of $\$ 31$ million is available over four years to provide a $\$ 5.50 /$ Watt subsidy for photovoltaic systems installed on house roofs. This subsidy is too small, even in combination with the $+2 \%$ requirement, to make conventional photovoltaics cost-effective. However, the program is likely to be fully utilised by people who want PV systems for power in remote regions or who like the idea of having an independent electricity supply.

There is a 50 per cent subsidy for displacement of diesel fuel by renewable electricity in stand-alone diesel electric systems. The source of this money is the excise paid by companies on the diesel fuel used to produce electricity in power stations in remote communities. Most of these systems are in Western Australia and the Northern Territory. Some of these remote power stations are being converted to natural gas, which will reduce the amount of excise payable and hence the pool of funds available for subsidisation of renewable electricity in these communities. Between $\$ 100$ and $\$ 200$ million is likely to be available over the next four years, but these funds may not be fully used due to a lack of co-funding commitment by the states. 
Funding has been made available through the Renewable Energy Commercialisation Program to assist with the commercialisation of renewable energy technologies. Funding of up to $\$ 1$ million per project (up to 50 per cent) is available. Several state governments offer renewable energy assistance programs.

\subsection{R\&D in Australia}

Renewable energy R\&D in Australia is in serious trouble. There is no direct Federal Government funding of renewable energy R\&D from any source. Australian Universities have virtually ceased to fund R\&D of any type. Grant Applications to the Australian Research Council have only a one in five chance of success. Tight restrictions on eligibility for government assistance for R\&D under various programs means that longer term $\mathrm{R} \& \mathrm{D}$ (> 3 years) is very difficult to fund. Remarkably, no funds whatever from the hundreds of millions of dollars of support for renewable energy that will flow through the Australian Greenhouse Office are available for research or development.

They are only two large R\&D groups in Australia in the area of renewable energy generation, namely those associated with the University of New South Wales and the Australian National University. Renewable energy R\&D is often a broad endeavour since it generally deals with complex systems with widely differing components. A critical mass of people, skills, equipment and resources is necessary. Research laboratories are very expensive to operate. The need to service overheads from commercial projects means that very few resources can be devoted to blue skies research. This regrettable situation means that Australian research groups are running down their intellectual capital. Without a change in policy it is likely that most of the commercialisation funds flowing through the Australian Greenhouse Office will be used for the commercialisation of foreign technology.

\subsection{Solar Electricity}

Markets for solar electricity in Australia over the next decade are likely to be largely driven by subsidies available from the Federal Government. The PV rooftop subsidy scheme is likely to be fully subscribed. An important factor that has yet to be determined is the price that electricity utilities will pay for PV electricity generated on house roofs. Attractive buyback rates have been established by law in several countries. If the Australian rate is set too low, then Australia will not share in the growing world market for roof mounted PV systems.

PV is also likely to be a major beneficiary of the diesel excise subsidy scheme. Biomass is not generally available in these remote areas. Wind energy will be clearly favoured in coastal locations or in areas with particularly good wind resources. However, most of the communities are in the north and west of Australia where wind resources are poor. Most of the diesel systems have a capacity in the range 0.1 to $1 \mathrm{MW}$. This is too small for cost-effective STE systems.

The cost of diesel electricity in the larger systems (for those generating companies paying excise) is in the range 18 to $30 \mathrm{c} / \mathrm{kWh}$, most of which is for fuel and maintenance. Small systems produce electricity at a cost of up to $\$ 1 / \mathrm{kWh}$. Mass PV systems which can produce electricity at an unsubsidised cost of $40 \mathrm{c} / \mathrm{kWh}$ will be fully economic, taking into account the diesel excise and $+2 \%$ subsidy schemes. It is

highly likely that concentrator systems, such as the ANU PV/Trough system, will meet this requirement. 


\subsection{Wind Energy}

It is not feasible to start an Australian wind generator industry from scratch. Although there are a number of skilled Australian manufacturers of small $(2-20 \mathrm{~kW})$ wind generators such as Westwind, there is a large technology jump to a modern multi megawatt machine. The most feasible route to an Australian manufacturing industry is by manufacture under licence. Even small-scale wind generator installation involves significant local content: shipping, foundations, electrical connections and often the tower. However, the high value parts of the wind generator (the blades, nacelle mechanics, generator, power electronics and computer controller) need to be imported for small-scale installation. A minimum production scale of $50 \mathrm{MW}$ per year will probably be required to persuade a major company to establish local manufacture of the latter items. There is no large wind generator manufacturing in SE Asia or Australasia at present. It is only a matter of time until this occurs, to service the region.

The requirements imposed by the $+2 \%$ obligation are very likely to lead to significant wind generator installation in Australia. A possible outcome is that the $9500 \mathrm{GWh} /$ year target for 2010 will be met with contributions of a quarter from each of wind energy, biomass, solar hot water (as an electricity substitute) and others. This will require the installation of about $800 \mathrm{MW}$ of wind generator capacity worth around $\$ 1.2$ billion. The $50 \mathrm{MW} /$ year minimum required to set up local manufacture in Australia would be met within a few years.

Tasmania is well placed to lead the Australian wind energy industry. A detailed study showed that at least $100,000 \mathrm{GWh} /$ year of wind energy (about 10 times larger than the $+2 \%$ target) could be generated after excluding all sites that have potential conflicts with urban, industrial, agricultural, forestry, cultural or environmental values [16] (although such a large-scale program is unlikely). Several prospective areas have high voltage transmission lines nearby which allows the avoidance of high connection costs. Tasmania's hydro system works well with wind energy since hydroelectricity can respond very quickly to fluctuating wind generator outputs and allows low cost storage of energy. Hydro Tasmania is keen to establish Basslink, a high voltage DC link to Victoria. This would allow the sale of Tasmanian hydroelectricity at peaking prices and the import of base load coal fired electricity for drought proofing. Tasmanian wind power could be exported to the mainland and would command premium prices due to the $+2 \%$ requirement. The cost of new generation options in Tasmania will be greater than $6 \mathrm{c} / \mathrm{kWh}$ because of the lack of suitable local fossil fuels.

Western Australia is isolated from the eastern Australian grid. It has abundant gas but relatively poor quality local coal. Sites in the SW corner have been measured to have average wind speeds at $30 \mathrm{~m}$ height of over $8 \mathrm{~m} / \mathrm{sec}$. South Australia has many excellent wind sites but relatively poor quality local coal. It is connected to the eastern Australian grid but not strongly. Provided that a suitable price for wind energy is offered there are attractive opportunities in this state. The markets in NSW, Victoria and Qld will be difficult to penetrate with wind energy (apart from demonstration scale projects).

\subsection{Encouragement of Solar and Wind Generated Electricity}

In the long term, the major constraint for solar and wind electricity in Australia is the low price of electricity from coal and gas. Fossil fuels are costed at the extraction price. It has been argued that insufficient penalties for the emission of greenhouse gases and other environmental pollutants are applied. Factors that will assist solar and wind electricity in the long term include: 
- A particularly sunny or windy site

- Absence of a grid

- A requirement for end-of-line grid support (to reduce transmission \& distribution losses and to eliminate the need for transformer or grid reinforcement in a relatively remote region with a growing load)

- Absent or weak connection to the main SE Australian grid (eg WA \& Tasmania and north Qld \& SA to a lesser extent)

- A desire to showcase the technology

- Green power

- Wheeling: this is where a company owns an electricity generator, and leases part of the capacity of the state grid to bring power to its factory. The company then avoids the retail cost of electricity, which is much higher than the pool price.

- Favourable government mandated buyback prices for renewable electricity

- The extension of government assistance schemes

Adjustments to energy policy in Australia could include:

- A serious attempt by the Government to meet Australia's Kyoto commitments

- Modification to Australia's hostile international stance to controls on greenhouse gas emissions

- Establishment of a $+10 \%$ policy for 2020 to follow on from the $+2 \%$ policy for 2010

- Introduction of a carbon tax or tradeable $\mathrm{CO}_{2}$ emission permits

- Establishment of a substantial R\&D fund for renewable energy

\section{Conclusion}

Wind energy, solar thermal electricity and photovoltaics are the only truly large-scale sustainable electricity generation technologies available. They are the only technologies that could completely displace fossil fuels over the next 50 years. These technologies are almost free of adverse environmental impacts. Unfortunately the cost of fossil fuel electricity generation is effectively subsidised by the failure to properly include environmental costs.

Wind energy is now a conventional generation technology. Several countries produce 10 per cent of their electricity from wind energy, and 10 per cent of the world's electricity is likely to come from the wind by the year 2020. In good sites, wind energy is competitive with all but the cheapest coal fired electricity. Australia has excellent wind energy resources by world standards.

Photovoltaics has found attractive niche markets in remote areas and small systems. In addition, several countries have embarked on ambitious programs to subsidise PV systems on house roofs. Costs are declining, but are still much higher than electricity from the grid. Two new subsidy schemes available from the Australian government (the $+2 \%$ scheme and the diesel excise subsidy scheme) will open a substantial market for PV systems over the next four years.

Solar thermal electricity suffers from a lack of niche markets. STE systems need to be large to have reasonable costs. However, large systems generally must compete directly with the state grids, whose costs are substantially lower. The $+2 \%$ scheme and the diesel excise subsidy scheme are not likely to be of great assistance to STE systems because the market will favour PV over STE. There are presently no 
commercial sales of STE systems anywhere in the world. It is difficult to see this situation changing in the near term unless substantial inducements are offered.

It is likely that international concern over the enhanced greenhouse effect will continue to increase. The consequence of this concern will be ever increasing support for wind, photovoltaic and solar thermal electricity. It is to be hoped that Australian government policies will be such as to place Australian companies in the forefront of the rapidly growing renewable energy industry. In particular, dedicated and strategically directed funding of $\mathrm{R} \& \mathrm{D}$ is required to complement funding made available for commercialisation.

\section{References and general reading}

1. Danish Wind Turbine Manufacturers Association, http://www.windpower.dk

2. eg ReSoft Windfarm (resoft@aol.com), WindFarmer (windops@ naturalpower.com)

3. A.W. Blakers, T. Crawford, M. Diesendorf, G. Hill and H. Outhred, "The Role of Wind Energy in Reducing Greenhouse Gas Emissions”, Report to the Department of the Arts, Sport, the Environment, Tourism and Territories, 1991.

4. Solar Radiation Data Handbook; ERDC 249; T. Lee, D. Oppenheim, T. Williamson

5. "European Wind Energy Association, Forum for Energy \& Development and Greenpeace, "Windforce 10", 1999

6. "Solar Thermal Power - a Historical, Technical and Economic Overview", S. Kaneff, Solar '96, Conference of the Australian and New Zealand Solar Energy Society

7. "A $400 \mathrm{~m}^{2}$ Aperture Power Dish", S. Kaneff, Solar '97, Conference of the Australian and New Zealand Solar Energy Society

8. "Market chances for solar thermal power plants", J. Benemann (Pilkington), Solar '99, Conference of the Australian and New Zealand Solar Energy Society

9. "Solar Thermal Power Systems", G.L. Morrison, D.R. Mills and Stanwell Corporation, Solar '99

10. "A large scale solar concentrator for economical power generation", Ian Moore and Allan Yeomans, Solar '99, Conference of the Australian and New Zealand Solar Energy Society

11. "Solar Thermal Power", L. Jesch, Renewable Energy World, p52, 1998

12. "Solar ponds at RMIT", A. Akbarzadeh et al, Solar '99, Conference of the Australian and New Zealand Solar Energy Society

13. "Solar Ammonia Energy Storage", Keith Lovegrove, Andreas Luzzi and Hoger Kreetz, Solar '99, Conference of the Australian and New Zealand Solar Energy Society

14. "The Promise of Concentrators", R.M. Swanson, Progress in Photovoltaics, Vol 8, pp93-111, 2000

15. See http://www.anu.edu.au/engn/solar

16. Greenwood, 'Utilization of Wind Energy in Tasmania', HECT, 1984/85

\section{Acknowledgements}

Valuable comments on the manuscript from the referees, Harry Schaap and Hugh Saddler, are gratefully acknowledged. 